greckiego, jak i po zawiłościach kwestii doktrynalnych. Umiejętnie wyprowadzane z materiału źródłowego przekonujące wnioski konfrontuje o. Pancerz ze stanowiskami współczesnych badaczy. Nie cytuje ich jednak bezkrytycznie, lecz prowadzi z nimi rzeczową i niejednokrotnie polemiczną dyskusję (przykładem

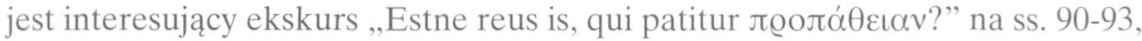
w którym Autor krytycznie ustosunkowuje się do niektórych stwierdzeń R. Laytona oraz polemika z A. Gesché na s. 103). Należy podkreślić również zdolność Autora do syntetycznego, uporządkowanego przedstawiania wniosków z przeprowadzonych szczegółowych analiz, czego przykładem może być jasne i przejrzyste wyszczególnienie charakterystycznych cech $\pi \varrho 0 \pi \alpha ́ \alpha \varepsilon ı \alpha$ w ujęciu Dydyma ze wskazaniem na oryginalność jego koncepcji (s. 89).

Rozprawa o. Pancerza została przygotowana starannie od strony formalnej. Autor - jak przystało na absolwenta renomowanej rzymskiej uczelni - posługuje się perfekcyjnie językiem łacińskim w sposób czynny. W napisanej po łacinie rozprawie nie znalazłem ani błędów stylistycznych ani nawet literówek. Na pochwałę zasługuje również bezbłędne opracowanie cytatów greckich. O. Pancerz dysponuje nieczęsto spotykaną umiejętnością klarownego omawiania skomplikowanych zagadnień. Tekst nie jest przeładowany, Autor bardzo precyzyjnie i logicznie wykłada zagadnienia bez zbędnych słów czy powtórzeń.

Dysertacja o. Pancerza stanowi cenne opracowanie z zakresu chrystologii patrystycznej, które zarówno pod względem merytorycznym, jak i metodologicznym, dorównuje analogicznym uznanym opracowaniom zachodnim. Autor zbadał kwestie dotąd nieporuszone w badaniach nad Dydymową koncepcją duszy Jezusa i dokonał syntezy nauki aleksandryjskiego mnicha w tej kwestii. Wyłaniający się z pracy obraz Dydyma jako teologa duszy ludzkiej Chrystusa, dobrze charakteryzuje zdanie kończące rozprawę: „Breviter dicendum est virum Alexandrinum fuisse in primis doctorem affectuum Christi” (s. 120).

Ks. Mariusz Szram - Lublin, KUL

\title{
Tomasz DEKERT, Teoria rekapitulacji Ireneusza z Lyonu w świetle starożyt- nych koncepcji na temat Adama, Kraków 2007, Wydawnictwo WAM, ss. 148.
}

Książka Tomasza Dekerta wpisuje się w kontynuację dzieła podjętego przez Wydawnictwo WAM, polegającego na swoistej promocji teologii wczesnochrześcijańskiej w dzisiejszym świecie. W zachęcającym tytule Autor zaprasza do podziwiania „krajobrazów” myśli teologicznej wykreowanych, czy może lepiej odkrytych, przez biskupa Lyonu w II wieku chrześcijaństwa. Tytuł klarownie ukazuje, iż autor w treści swego dzieła będzie zajmował się jedną z ciekawszych koncepcji soteriologicznych, jakie spotykamy u Ojców Kościoła. 
O autorze opracowania nic się nie dowiemy, bowiem książka nie zawiera osobnej noty biograficznej. Pozostaje nam lakoniczna informacja ze stron internetowych, z których się dowiadujemy, że Tomasz Dekert urodzony w 1979 r., jest doktorantem religioznawstwa na Uniwersytecie Jagiellońskim i pracuje w Dominikańskim Centrum Informacji o Nowych Ruchach Religijnych i Sektach w Krakowie (por. stronę: http//www.teofil.dominikanie.pl/ $? \mathrm{f}=$ artykul\&id=2078\&nr=20). Sposób prowadzenia badań przez autora wskazuje na jego bardzo dobre przygotowanie metodologiczne w dziedzinie patrystyki.

Książka Tomasza Dekerta zajmuje się teorią rekapitulacji u Ireneusza z Lyonu, która, jak sam zaznacza we wstępie, nie jest zagadnieniem nieznanym. Istnieją bowiem opracowania, w których jest ona tematem głównym (np. H. Scharl, Recapitulatio mundi. Rekapitulationsbegriff des hl. Irenäus und seine Anwendung auf die Körperwelt, Freiburg 1941), lub ubocznym (np. H. Schlier,

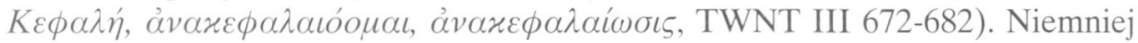
w języku polskim teoria rekapitulacji św. Ireneusza nie doczekała się osobnego większego opracowania, aczkolwiek w wielu leksykonach, antologiach, czy podręcznikach patrystycznych, z których Tomasz Dekert korzysta, jest ona dosyć dobrze i syntetycznie opracowana. W naszym języku dostępne są m.in. opracowania dotyczące takich aspektów teologii św. Ireneusza, jak związek Ducha Świętego z Kościołem (B. Częsz, Związek Ducha Świętego z Kościołem w ujęciu św. Ireneusza i w interpretacji monastycznej, Poznań 1991), symbolika krzyża (W. Myszor, Symbolika krzyża według św. Ireneusza, SSHT 30:1979, 97-102), angelologia (H. Pietras, Aniołowie w teologii Ireneusza z Lyonu na tle tradycji judeo-chrześcijańskiej, „Terminus” 2:2000, 51-57), czy grzech pierworodny (H. Pietras, Pierwszy grzech ludzi wedtug św. Ireneusza, w: Grzech pierworodny, red. H. Pietras, ŹMT 12, Kraków 1999, 86-98). Nowatorstwo książki Dekerta polega na specyficznym podejściu do teorii rekapitulacji. Całość wywodów i badań ma umożliwić czytelnikowi spojrzenie, jak pisze Autor we wstępie (s. 10), ,z zewnątrz" na tę koncepcję. Celem tego jest zapoznanie się z niepochodzącymi od chrześcijaństwa koncepcjami antropologicznymi, które mogły mieć wpływ na wykreowanie teorii Ireneusza. Autor będzie więc stale w toku swych badań konfrontował myśl biskupa z Lyonu z teoriami dotyczącymi początków świata i człowieka w literaturze pogańskiej, judaistycznej i gnostyckiej. Sugeruje to już sam tytuł, w którym pojawia się imię pierwszego biblijnego człowieka.

Układ pracy jest przejrzysty i zgodny z zasadami metodologii patrystycznej, akceptowanej przez większość badaczy. Książka składa się z trzech rozdziałów poprzedzonych wstępem (ss. 9-16) z założeniami dotyczącymi tematu, które autor następnie weryfikuje i podsumowuje w zakończeniu, zatytułowanym „Adam a teorie rekapitulacji” (ss. 126-134). W pierwszym rozdziale pt. „Teoria rekapitulacji Ireneusza z Lyonu w aspekcie pojęciowym i koncepcyjnym" 
(ss. 17-41) mamy rozłożony przed sobą różnobarwny wachlarz pojęć i koncepcji dotyczących głównego przedmiotu opracowania; Autor przeprowadza w tym rozdziale wyczerpującą analizę filologiczną i kulturową terminu „rekapitulacja”. Drugi rozdział pt. „Chrystus i Adam w teorii rekapitulacji” (ss. 42-75) poświęcony jest podmiotowi teorii rekapitulacji, czyli osobie Chrystusa. Tutaj możemy przekonać się, jak Tomasz Dekert jest konsekwentny w swoim działaniu. Badanie filologiczne greckiego terminu nakefalaiw pozwoliło mu wyciągnąć wnioski co do działalności Chrystusa w związku z rekapitulacją w aspekcie zawierania i powtarzania. W oparciu o nie przedstawia, jak w nurcie zstępującym wygląda zbawcze działanie Boga według Ireneusza. W końcu trzeci rozdział zatytułowany „Adam” (ss. 76-125), najobszerniejszy, poświęcony jest osobie Adama, w ujęciu jednostkowym, jak i ogólnym, dotyczącym człowieka w ogóle. Tu również mamy na początku rozpracowaną kwestię terminologii. Okazuje się, że do pełnego obrazu Ireneuszowej teorii rekapitulacji czymś nieodzownym jest poznanie, jak rozumiano słowo adam przed i po Chrystusie. Ponieważ teoria rekapitulacji jest jedną z koncepcji na temat zbawienia, w rozdziale tym mamy poruszony także wątek upadku człowieka i świata.

Tomasz Dekert, jak już wspomniałem, poprawnie korzysta ze źródeł. Wystarczy wspomnieć, iż przeprowadzając badania heurystyczne, poszukuje w piśmiennictwie judaistycznym, pozabiblijnym, uwzględnia nurt kultury greckiej, a także wykorzystuje apokryfy i pisma gnostyckie. Równie poprawnie stosuje zasady hermeneutyki patrystycznej, wykorzystując analizę filologiczną i porównawczą przedstawionych źródeł. Jednocześnie dokonuje świadomej weryfikacji źródeł w kluczu wywierania ich wpływu na myśl teologiczną Biskupa Lyonu. Wnioski, które wyciąga z analizy źródeł, układają się w logiczną całość, której z trudem można cokolwiek zarzucić. Autor nie tyle przedstawia bezpośrednie źródła, z których miałby korzystać Ireneusz, ale pewne koncepcje funkcjonujące w świecie współczesnym Biskupowi Lyonu, które mogły zainspirować takie a nie inne jego spojrzenie na eschatologię. Dekert skupia się głównie na żydowskiej koncepcji Adama, która, w jego odczuciu, miała wpływ na wizję zbawczej roli i działania Chrystusa u Ireneusza. Ta hipoteza, postawiona przez Autora opracowania, jest głównym wątkiem jego pracy. Nie ma tu mowy o nadinterpretacji źródeł, a fakt, że autor często je przytacza, nawet w języku oryginalnym, pozwala czytelnikowi samemu dojść do podobnych wniosków. Okazuje się, że Ireneusz mógł czerpać z dorobku egzegezy żydowskiej oraz rozumieć w znaczeniu hebrajskim kluczowy termin adam. Dekert bada, w jaki sposób te koncepcje mogły dotrzeć do Ireneusza. Wiele kwestii porusza on także w przypisach, nie tylko odsyłając do konkretnych opracowań czy autorów, ale również przytaczając obszerne nieraz passusy na dany temat. Czytelnik otrzymuje również sporą dawkę wolności. Wnioski bowiem mają charakter hipotetyczny, zbudowany jednak na mocnych przesłankach, z którymi trzeba się zgodzić. 
Książka Tomasza Dekerta, choć jest opracowaniem stricte naukowym, dzięki kunsztowi autora przydatna jest dla szerokiego grona odbiorców. Z pewnością dużo wnosi w badania nad źródłami teologii chrześcijańskiej i mogą z niej korzystać zarówno ci, którzy tą dziedziną zajmują się na co dzień, jak i ci dla których jest ona nowością. Sądzę, że jest ona atrakcyjna nie tylko dla patrologów czy dogmatyków. Sam pomysł badania źródeł jednej z najciekawszych i ważnych teorii dotyczących zbawienia powinien zachęcić każdego, kto poszukuje głębi wiary chrześcijańskiej. Poznawanie bowiem kontekstów, w jakich rodziły się prawdy wiary, może otworzyć na nie mentalność człowieka współczesnego tak odpornego na dogmaty.

Ks. Szymon Górski - Kielce

\section{Elżbieta DOŁGANISZEWSKA, Biskup Cyprian z Kartaginy. Świadek wia- ry, Wrocław 2007, Wydawnictwo Wrocławskiej Księgarni Archidiecezjalnej, ss. 104.}

Postaci wielkich animatorów życia społecznego, politycznego i religijnego zawsze są z chęcią przywoływane i opisywane, a ich życie, działalność i twórczość przypominane są wciąż na nowo. Szczególnie w patrologii, zajmującej się postaciami pisarzy chrześcijańskich pierwszych wieków, znajomość środowiska, życia i dzieł danego pisarza wydaje się nieodzowna. Oprócz standartowych podręczników, które z oczywistych względów przedstawiają tylko najważniejsze informacje biograficzne, ważną rolę odgrywają monografie dotyczące poszczególnych pisarzy, umieszczające ich w konkretnym kontekście oraz prezentujące podstawy ich teologii i swoisty klucz hermeneutyczny do zrozumienia ich twórczości. W ostatnim czasie w Polsce rolę te spełnia częściowo seria Wielcy Ludzie Kościoła, publikowana przez Wydawnictwo WAM. Pojawiają się także inne pozycje poza seriami, które mają za cel przybliżenie tych wybitnych postaci. Jedną z nich jest opublikowana przez Wydawnictwo Wrocławskiej Księgarni Archidiecezjalnej książka Elżbiety Dołganiszewskiej Biskup Cyprian z Kartaginy. Swiadek wiary.

Składająca się z sześciu rozdziałów praca, zgodnie ze słowami autorki, ma „w ogólnych zarysach ukazać sylwetkę - życie i dzieło - tegoż właśnie niezwykłego biskupa, świadka wiary i męczennika z Kartaginy" (s. 8). Autorka z rozmachem zmierza do postawionego sobie celu. W pierwszym rozdziale „Cyprian, biskup Kartaginy" (ss. 9-22) przedstawia życiorys Cypriana w kontekście prześladowanego Kościoła i problemów z upadłymi oraz z kościelną jednością. Drugi rozdział „Dzieła teologiczne biskupa Cypriana” (ss. 23-38) ma za cel ukazanie bogatej spuścizny literackiej biskupa Kartaginy. „Sakrament chrztu zalążkiem jedności Kościoła” to tytuł trzeciego rozdziału (ss. 39-50), 